Jurnal Keperawatan Silampari

Volume 4, Nomor 2, Juni 2021

e-ISSN: 2581-1975

p-ISSN: 2597-7482

DOI: https://doi.org/10.31539/jks.v4i2.1650

\title{
PERUBAHAN KUALITAS TIDUR IBU HAMIL TRIMESTER III MELALUI PREGNANCY MASSAGE
}

\author{
Nana Fitriana \\ Universitas Negeri Semarang \\ nanaf4354@gmail.com
}

\begin{abstract}
ABSTRAK
Penelitian ini bertujuan untuk mengetahui pengaruh pregnancy massage terhadap perubahan kualitas tidur ibu hamil trimester III di Desa Klepu Kabupaten Semarang. Metodel dalam penelitian ini adalah penelitian kuantitatif dengan desain penelitian quasy eksperimen menggunakan pre test- post test with control group. Hasil penelitian ini menunjukan bahwa p-value $0,001<(0,05)$ yaitu ada perbedaan secara signifikan pengaruh pregnancy massage terhadap perubahan kualitas tidur ibu hamil trimester III.Rata-rata nilai kualitas tidur pada kelompok intervensi sebesar 11,60 lebih kecil dibandingkan ratarata nilai kualitas tidur pada kelompok control sebesar 17,20. Simpulan, terdapat pengaruh intervensi pregnancy massage terhadap perubahan kualitas tidur ibu hamil trimester III di Desa Klepu kabupaten Semarang.
\end{abstract}

Kata Kunci : Ibu Hamil Trimester III, Kualitas tidur, Pregnancy massage

\begin{abstract}
This study aims to determine the factors that affect dietary compliance in patients with type II diabetes mellitus, including family support, knowledge, income, and nutritional counseling. The research method used in this study is cross-sectional. This study indicates a relationship between family support, understanding, revenue, and nutritional counseling on dietary compliance in older people with type II diabetes Mellitus in 2019 in a district in Jambi. In conclusion, there is a relationship between family support, knowledge, income, and nutritional counseling on dietary compliance in older people with type II diabetes Mellitus.
\end{abstract}

Keywords: Diabetes Mellitus, Family Support, Knowledge, Nutrition Counseling

\section{PENDAHULUAN}

Ibu hamil mengalami perubahan secara fisik, beberapa fisik ini dapat mengakibatkan stress dan rasa tidak nyaman (Yusmaharani, 2019; Mariana et al., 2018). Pijat selama kehamilan merupakan salah satu cara yang sesuai untuk mengurangi stress dan meningkatkan kesejahteraan ibu dan bayi. Manfaat dan keuntungan dari pijat hamil diantaranya meningkatkan relaksasi, meningkatkan pola tidur, membantu mengurangi oedema, mendukung kesehatan uterus, mengurangi ketegangan, stress mengurangi nyeri dan kecemasan, memperbaiki perubahan postur tubuh pada kehamilan, menciptakan hubungan yang harmonis antara ibu dan bayi, mengurangi nyeri punggung, bahu dan leher pada ibu hamil dan kondisi otot secara umum pada kehamilan, membantu menstabilkan perubahan hormonal dan tekanan darah, mendorong bernafas lebih dalam, 
meningkatkan respirasi internal, mengurangi mual, merangsang aktifitas peristaltic, mengurangi ketegangan otot, mengembalikan keseimbangan postur tubuh, menormalkan berbagai gerak sendi, mempercepat sirkulasi vena dan getah bening, membawa nutrisi ke jaringan dan menghilangkan produk-produk racun dari tubuh, mengurangi pembengkakan, meredakan varises, menormalkan tekanan darah, mengangkat suasana hari atau mood, mendorong perawatan ibu yang penuh kasih, mempersiapkan fisik, emosional dan mental ibu untuk menghadapi nifas (Prananingrum \& Hidayah, 2018).

Menurut Rufaida et al., (2020) pregnancy massage dapat mengurangi rasa tidak nyaman dan sakit pada daerah punggung selama kehamilan, dikarenakan dengan pregnancy massage dapat mengurangi kelelahan dan membuat tubuh lebih berenergi dengan cara mengeluarkan produk metabolisme dalam tubuh limfatik dan sistem sirkulasi. Ketidaknyamanan ibu hamil seperti kram, ketegangan otot dan kekauan otot dapat berkurang setelah dilakukan pijat karena sirkulasi yang lancar memudahkan kerja jantung dan tekanan darah sehingga ibu hamil merasa lebih segar. Selain hal tersebut hormon endorphin yang dihasilkan saat pemijatan akan mempermudah ibu menjadi relax.

Pregnancy massage atau pijat kehamilan merupakan terapi non farmakologis yang bertujuan untuk meningkatkan kesejahteraan ibu dan janin (Resmaniasih, 2018). Beberapa faktor dominan yang menstimlasi terjadinya gangguan kualitas tidur ibu hamil antara lain kecemasan menghadapi kehamilan, ketidaknyamanan selama kehamilan akibat seringnya buang air kecil, hipersaliva dan mendengkur serta kram (Palifiana \& Wulandari, 2018). Gangguan tidur dapat menyebabkan gangguan hormonal dalam tubuh. Gangguan tidur dapat meningkatkan adanya resiko Diabetes Melitus (DM), peningkatan tekanan darah dan resiko gangguan tumbuh-kembang janin dalam kandungan (Bustami et al., 2017; Kurnia et al., 2017).

Berdasarkan data yang diperoleh di awal penelitian di Desa Klepu Kabupaten Semarang, jumlah ibu hamil trimester III berjumlah 20 orang. Dari hasil studi pendahuluan yang dilakukan tanggal 5 Juli 2017 bahwa dari 9 ibu hamil 6 diantaranya mengalami kesulitan tidur. Kesulitan tidur dapat menimbulkan depresi dan stress yang berpengaruh pada janin yang dikandungnya. Stress ringan menyebabkan janin mengalami peningkatan denyut jantung, tetapi stress berat dan lama akan membuat janin menjadi hiperaktif. Kesulitan tidur ini dikarenakan perut ibu semakin membesar sehingga ibu sulit untuk mendapatkan posisi yang nyaman dan perasaan cemas ibu menjelang persalinan serta keluhan sering BAK. Keluhan ini dirasakan oleh ibu sebagai hal yang wajar karena memasuki akhir kehamilan sehingga ibu belum melakukan terapi untuk mengatasi kesulitan tidurnya.

Penelitian tentang pregnancy massage sudah pernah dilakukan tapi mayoritas hanya melihat bagaimana pregnancy massage mempengaruhi kenyamanan selama kehamilan pada ibu hamil saja, namun pada penelitian ini berfokus pada pemberian intervensi pregnancy massage terhadap kualitas tidur ibu hamil trimester III.

\section{METODE PENELITIAN}

Penelitian ini merupakan penelitian eksperimen dengan rancangan pre test-post test with control group. Populasi pada penelitian ini adalah Ibu hamil trimester III yang ada di Desa Klepu Kecamatan Pringapus Kabupaten Semarang. Populasi ibu hamil trimester III sebanyak $20 \mathrm{ibu}$ hamil. Teknik pengambilan sampel dalam penelitian ini menggunakan teknik purposive sampling yaitu 20 responden yang dibagi menjadi 2 kelompok yaitu 10 responden pertama dijadikan sebagai kelompok perlakuan yang menerima pregnancy massage dan 10 responden kelompok kedua sebagai kelompok kontrol. 
Pregnancy massage diberikan 2 kali dalam seminggu. Instrumen yang digunakan dalam penelitian ini adalah kuesioner kualitas tidur PSQI yang sudah dimodifikasi oleh peneliti. Analisis univariat difokuskan pada mean standar deviasi dan nilai maximum dan minimum sedangkan analisis bivariat dengan uji independent $t$-test (paired t-test).

\section{HASIL PENELITIAN}

Tabel. 1

Deskripsi Berdasarkan Kualitas Tidur Ibu Hamil Trimester III Sebelum Dilakukan Pregnancy massage

\begin{tabular}{ccccccc}
\hline Variabel & Kelompok Intervensi & N & Mean & SD & Min & Max \\
\hline Kualitas Tidur & Pretest & 10 & 17,90 & 3,11 & 13 & 23 \\
\hline
\end{tabular}

Berdasarkan tabel 1 dapat diketahui bahwa sebagian besar responden ibu hamil trimester III di Desa Klepu kabupaten Semarang sebelum diberikan pregnancy massage memiliki kualitas tidur buruk yaitu rata-rata sebesar 17,90 dengan standar deviasi 3,11 dimana minimal total skor 12 dan maximal total skor 23.

Tabel. 2

Deskripsi Berdasarkan Kualitas Tidur Ibu Hamil Trimester III Setelah Dilakukan Pregnancy massage

\begin{tabular}{lclllll}
\hline Variabel & Perlakuan & $\mathrm{N}$ & Mean & SD & Min & Max \\
\hline Kualitas Tidur & Posttest & 10 & 11,60 & 3,95 & 6 & 19 \\
\hline
\end{tabular}

Berdasarkan tabel 2 dapat diketahui bahwa sesudah diberikan pregnancy massage pada kelompok Intervensi, rata-rata kualitas tidur ibu hamil trimester III bernilai 11,60 dengan standar deviasi 3,95 nilai skor terendah 6 dan nilai skor tertinggi 19.

Tabel. 3

Deskripsi Berdasarkan Kualitas Tidur Ibu Hamil Trimester III Sebelum Penelitian pada kelompok Kontrol

\begin{tabular}{llccccc}
\hline Variabel & Kelompok Kontrol & N & Mean & SD & Min & Max \\
\hline Kualitas Tidur & Pretest & 10 & 17,60 & 2,17 & 14 & 21 \\
\hline
\end{tabular}

Berdasarkan tabel 3 dapat diketahui bahwa kualitas tidur ibu hamil trimester III sebelum penelitian pada kelompok kontrol, rata-rata kualitas tidur ibu hamil trimester III bernilai 17,60 dengan standar deviasi 2,17, nilai skor terendah 14 dan nilai skor tertinggi 21.

Tabel. 4

Deskripsi berdasarkan Kualitas Tidur Ibu Hamil Trimester III

Sesudah Penelitian pada Kelompok Kontrol

\begin{tabular}{rllllll}
\hline Variabel & Kelompok Kontrol & $\mathrm{N}$ & Mean & SD & Min & Max \\
\hline Kualitas Tidur & Posttest & 10 & 17,20 & 1,75 & 15 & 20 \\
\hline
\end{tabular}


Berdasarkan tabel 4 dapat diketahui bahwa kualitas tidur ibu hamil trimester III sesudah penelitian pada kelompok kontrol, rata-rata kualitas tidur ibu hamil trimester III bernilai 17,20 dengan standar deviasi 1,75, nilai skor terendah 15 dan nilai skor tertinggi 20 .

Tabel. 5

Perbedaan Kualitas Tidur Ibu Hamil Sebelum dan Sesudah Diberikan Pregnancy massage pada Kelompok Intervensi

\begin{tabular}{ccccccc}
\hline Variabel & Perlakuan & N & Mean & SD & T & $p$-value \\
\hline Kualitas Tidur & Pretest & 10 & 17,90 & 3,11 & 6,763 & 0,000 \\
& Posttest & 10 & 11,60 & 3,95 & & \\
\hline
\end{tabular}

Berdasarkan tabel 5 dapat diketahui bahwa sebelum diberikan pregnancy massage, rata-rata skor kualitas tidur ibu hamil sebesar 17,90. Kemudian turun menjadi 11,60 sesudah diberikan pregnancy massage. Skor kualitas tidur turun menunjukkan peningkatan kualitas tidur. Uji t dependen, didapatkan nilai t hitung sebesar 6,763 dengan p-value 0,000 .

Tabel. 6

Perbedaan Kualitas Tidur Ibu Hamil Sebelum dan Sesudah Penelitian pada Kelompok Kontrol

\begin{tabular}{ccccccc}
\hline Variabel & Perlakuan & $\mathrm{N}$ & Mean & SD & T & p-value \\
\hline Kualitas Tidur & Pretest & 10 & 17,60 & 2,17 & 0,937 & 0,373 \\
& Posttest & 10 & 17,20 & 1,75 & & \\
\hline
\end{tabular}

Berdasarkan tabel 6 dapat diketahui bahwa pada kelompok kontrol, sebelum penelitian, rata-rata skor kualitas tidur ibu hamil sebesar 17,60. Kemudian berubah menjadi 17,20 sesudah penelitian. Berdasarkan uji t dependen, didapatkan nilai t hitung sebesar 0,937 dengan $p$-value 0,373 .

Tabel. 7

Pengaruh Pemberian Pregnancy massage terhadap Kualitas Tidur Ibu Hamil

\begin{tabular}{clccccc}
\hline Variabel & \multicolumn{1}{c}{ Kelompok } & $\mathrm{N}$ & Mean & $\mathrm{SD}$ & $\mathrm{T}$ & p-value \\
\hline Kualitas Tidur & Intervensi & 10 & 11,60 & 3,95 & - & 0,001 \\
& Kontrol & 10 & 17,20 & 1,75 & 4,099 & \\
\hline
\end{tabular}

Berdasarkan tabel 7 dapat diketahui bahwa pada kelompok intervensi, sesudah diberikan pregnancy massage, rata-rata skor kualitas tidur ibu hamil sebesar 11,60. Ini lebih rendah dibandingkan kelompok control yang tidak diberikan pregnancy massage, sebesar 17,20. Skor kualitas tidur yang rendah menunjukkan kualitas tidur yang lebih baik. Berdasarkan uji t independen, didapatkan nilai t hitung sebesar -4,099 dengan $p$ value 0,001 . 


\section{PEMBAHASAN}

Tabel 1 dapat diketahui bahwa sebagian besar responden ibu hamil trimester III di Desa Klepu kabupaten Semarang sebelum diberikan pregnancy massage memiliki kualitas tidur buruk yaitu rata-rata sebesar 17,90 dengan standar deviasi 3,11 dimana minimal total skor 12 dan maksimal total skor 23. Di awal penelitian rata-rata ibu hamil pada kelompok intervensi membutuhkan jam tidur dimalam hari 5-6 jam dan terdapat 2 responden tidak istirahat disiang hari.

Pada penelitian ini 10 responden pada kelompok intervensi mengeluh sering mengalami gangguan tidur seperti nyeri punggung, terbangun untuk ke kamar mandi, susah mencari posisi yang nyaman untuk tidur dan mimpi buruk. Hal ini sejalan dengan Yantina \& Evrianasari (2020) berdasarkan uraian hasil penelitian di atas maka dapat dijelaskan bahwa terapi back massage terbukti signifikan dalam meningkatkan kualitas tidur ibu hamil hal ini dapat terjadi karena back massage membantu memperlancar metabolisme dalam tubuh sehingga aliran oksigen dalam darah meningkat dan memicu pengeluaran hormon endorphin yang merupakan zat kimia endogen (diproduksi oleh tubuh) yang terstruktur serupa dengan opioid (juga disebut sebagai opiat atau narkotik). Apabila tubuh mengeluarkan subtansi-substansi ini maka salah satu efeknya adalah memberikan rasa nyaman, senang dan rileks sehingga mampu memperbaiki psikologis dan ketegangan ibu hamil yang pada akhirnya mampu meningkatkan kualitas tidur bagi ibu hamil. Oleh karena itu, back massage dapat menjadi bagian dari terapi alternatif ataupun komplementer yang masuk dalam sistem pelayanan kesehatan khususnya untuk membantu meningkatkan kualitas tidur bagi ibu hamil terutama pada trimester ketiga.

Tabel 2 dapat diketahui bahwa sesudah diberikan pregnancy massage pada kelompok Intervensi, rata-rata kualitas tidur ibu hamil trimester III bernilai 11,60 dengan standar deviasi 3,95, nilai skor terendah 6 dan nilai skor tertinggi 19. Di penelitian ini bahwa setelah diberikan pregnancy massage pada 10 responden dengan kelompok intervensi, umumnya terjadi penurunan pada terjadinya nyeri punggung dan peningkatan waktu tidur yang lama yaitu berkisar 7 jam. Keluhan-keluhan yang sering dirasakan mulai berkurang dan merasa segar ketika bangun dari tidur di pagi hari. Pregnancy massage atau pijat kehamilan merupakan terapi non farmakologis yang bertujuan untuk meningkatkan kesejahteraan ibu dan janin (Resmaniasih, 2018; Rahayu et al., 2020). Kajian tentang efek/ manfaat dari pijat ibu hamil pada ibu hamil TM III antara lain meningkatkan kualitas tidur. Kualitas tidur ibu hamil digambarkan dengan kuantitas jam seorang ibu hamil dapat tertidur.(Wardani et al., 2018).

Tabel 3 dapat diketahui bahwa kualitas tidur ibu hamil trimester III sebelum penelitian pada kelompok kontrol, rata-rata kualitas tidur ibu hamil trimester III bernilai 17,60 dengan standar deviasi 2,17, nilai skor terendah 14 dan nilai skor tertinggi 21 . Di awal penelitian peneliti mendapatkan 2 responden dengan kualitas tidur baik dan 8 respon memiliki kualitas tidur yang buruk pada kelompok kontrol. Responden yang memiliki kualitas tidur yang buruk umumnya mengalami ketidaknyamanan yang dapat menganggu kualitas tidurnya seperti, nyeri punggung, dan sering kencing serta susah mencari posisi yang nyaman untuk tidur.

Pada trimester III penyebab ibu untuk tertidur karena adanya perubahan fisik yang signifikan, bobot yang bertambah membuat ibu terasa pegal, posisi tidur serba salah. Selain itu karena ketidaknyamanan antara lain peningkatan urinari, nyeri punggung dan cemas. Hal tersebut sesuai dengan penelitian. Penelitian menggambarkan bahwa kualitas tidur yang kurang dapat meningkatkan persalinan dengan SC 4,5 kali lipat dan meningkatkan resiko persalinan pre term. Beberapa faktor dominan yang menstimlasi 
terjadinya gangguan kualitas tidur ibu hamil antara lain kecemasan menghadapi kehamilan, ketidaknyamanan selama kehamilan akibat seringnya buang air kecil, hipersaliva dan mendengkur serta kram (Palifiana \& Wulandari, 2018).

Tabel 4 dapat diketahui bahwa kualitas tidur ibu hamil trimester III sesudah penelitian pada kelompok kontrol, rata-rata kualitas tidur ibu hamil trimester III bernilai 17,20 dengan standar deviasi 1,75, nilai skor terendah 15 dan nilai skor tertinggi 20. Responden kelompok kontrol umumnya masih mengalami kesulitan tidur dimalam hari. Keluhan yang mereka alami seperti sering berkemih dimalam hari, merasakan nyeri punggung dan ketidakmampuan ibu untuk langsung tidur dimalam hari.

Pada trimester III ibu hamil banyak mengalami gangguan seperti nyeri punggung, kram kaki, perut tidak nyaman, sering buang air kecil, gangguan pernafasan dan gangguan tidur. Kebutuhan tidur ibu hamil (dewasa) sekitar 7 - 8 jam (Sukorini, 2017). Gangguan tidur dapat menyebabkan gangguan hormonal dalam tubuh. Gangguan tidur dapat meningkatkan adanya resiko Diabetes Melitus (DM), peningkatan tekanan darah dan resiko gangguan tumbuh-kembang janin dalam kandungan (Bustami et al., 2017; Kurnia et al., 2017). Gangguan hormonal yang terjadi antara lain penurunan kadar hormon lepthin yang merupakan penanda seseorang menjadi kenyang dan peningkatan kadar hormone gherelin (penstimulasi nafsu makan) dapat menyebabkan adanya DM gestasional. Sedangkan kadar hormon adrenalin meningkat sehingga dapat meningkatkan kecemasan dan tekanan darah ibu. Kondisi resiko DM dan tekanan darah tinggi menyebabkan kenaikan resiko gangguan tumbuh kembang janin dalam kandungan (Bustami et al., 2017).

Tabel 5 dapat diketahui bahwa sebelum diberikan pregnancy massage, rata-rata skor kualitas tidur ibu hamil sebesar 17,90. Kemudian turun menjadi 11,60 sesudah diberikan pregnancy massage. Skor kualitas tidur turun menunjukkan peningkatan kualitas tidur. Uji t dependen, didapatkan nilai t hitung sebesar 6,763 dengan $p$-value 0,000 . Oleh karena $p$-value $0,000<(0,05)$, maka dapat disimpulkan bahwa ada perbedaan yang signifikan kualitas tidur sebelum dan sesudah diberikan pregnancy massage pada ibu hamil trimester III di Desa Klepu Kabupaten Semarang.

Sejalan dengan hasil penelitian ini diketahui bahwa hampir seluruh ibu bersalin yang diberikan prenatal massage dengan proses persalinan normal. Keadaan ini menunjukkan bahwa dengan diberikan prenatal massage pada ibu hamil dapat memperlancar pada proses persalinannya. Ibu bersalin yang saat kehamilannya diberikan prenatal massage dapat membantu menyelesaikan permasalahan seperti kecemasan, depresi, stress, nyeri dan insomnia dengan mengurangi ketegangan otot sehingga memperlancar proses persalinan (Sudarnanik et al., 2020).

Tabel 6 dapat diketahui bahwa pada kelompok kontrol, sebelum penelitian, rata-rata skor kualitas tidur ibu hamil sebesar 17,60. Kemudian berubah menjadi 17,20 sesudah penelitian. Berdasarkan uji t dependen, didapatkan nilai t hitung sebesar 0,937 dengan $p$ value 0,373 . Oleh karena $p$-value $0,373>\alpha \quad(0,05)$, maka dapat disimpulkan bahwa tidak ada perbedaan secara signifikan kualitas tidur sebelum dan sesudah penelitian pada kelompok kontrol pada ibu hamil trimester III di Desa Klepu Kabupaten Semarang.

Hasil penelitian yang dilakukan di Desa Klepu Kabupaten Semarang sebelum penelitian didapatkan hasil kualitas tidur yang baik sejumlah 2 responden (20\%), sedangkan ibu hamil yang memiliki kualitas tidur buruk sebanyak 8 orang (80\%). Sedangkan hasil setelah penelitian yang dilakukan di Desa Klepu Kabupaten Semarang di dapatkan kualitas tidur yang baik sejumlah 3 responden (30\%), sedangkan ibu hamil yang memiliki kualitas tidur buruk sebanyak 7 orang (70\%). Permasalahan yang sering ibu 
alami di awal penelitian yaitu sering buang air kecil di malam hari, nyeri pinggang sehingga menyebabkan keslitan tidur.

Hal ini menunjukan bahwa tidak ada perubahan kualitas tidur yang signifikan pada kelompok kontrol di awal penelitian maupun di akhir penelitian. Permaslahan yang sering dikeluhkan ibu hamil trimester III masih sering dialami oleh ibu hamil trimester III sampai di akhir penelitian. Penyebab kualitas tidur buruk adalah karena adanya peningkatan frekuensi BAK, kesulitan untuk bernafas, kepanasan atau gerah. Hal ini didukung oleh penelitian menurut National sleep Foundation, trimester III adalah tahap tidur yang paling menantang dari kehamilan. Dengan meningkatnya frekuensi dari buang air kecil, ketidakmampuan untuk merasa nyaman dan kelelahan dari kebiasaan setiap harinya.

Penelitian Resmaniasih (2018) menunjukkan bahwa ada pengaruh pijat hamil terhadap kualitas tidur pada ibu hamil trimester tiga. Hal ini mungkin disebabkan karena adanya perbedaan rerata kualitas tidur awal pada kedua kelompok. Ibu hamil trimester III yang menjadi kelompok intervensi/yang mendapatkan pijat, rerata kualitas tidurnya lebih tinggi $(6,69)$, sedangkan kelompok kontrol $(5,23)$. Kualitas tidur pada kelompok intervensi lebih buruk dari awal, dibandingkan kelompok kontrol.

Tabel 7 dapat diketahui bahwa pada kelompok intervensi, sesudah diberikan pregnancy massage, rata-rata skor kualitas tidur ibu hamil sebesar 11,60. Ini lebih rendah dibandingkan kelompok kontrol yang tidak diberikan pregnancy massage, sebesar 17,20. Skor kualitas tidur yang rendah menunjukkan kualitas tidur yang lebih baik. Berdasarkan uji t independen, didapatkan nilai t hitung sebesar -4,099 dengan $p$ value 0,001 . Oleh karena $p$-value $0,001<\alpha(0,05)$, maka dapat disimpulkan bahwa pengaruh secara signifikan pemberian pregnancy massage terhadap kualitas tidur ibu hamil trimester III di Desa Klepu Kabupaten Semarang.

Pregnancy massage ditujukan untuk para ibu yang sedang hamil agar dapat melahirkan bayinya dengan selamat dan lancar. Artikel penelitian terkait dengan efek pijat terhadap kecemasan ditulis oleh Lilis Surya Wati. Penelitian tersebut menggunakan desain true experiment dengan post-test only with control group design dengan masingmasing sampel sebanyak 15 orang ibu hamil TM III. Hasil penelitian menggambarkan ada perbedaan tingkat stres pada ibu hamil kelompok intervensi sebelum dan sesudah pemberian paket prenatal massage dengan $\rho$ value 0,047. Pada kelompok perlakuan, setelah pemberian paket prenatal massage tidak terdapat ibu dengan kategori stres $(0 \%)$, sedangkan sebelum intervensi terdapat $25 \%$ ibu yang mengalami stress (Wati, 2018).

Artikel penelitian yang ditulis Ni Luh Kade Suamiti menggambarkan bahwa pijat ibu hamil dapat menurunkan ketegangan saraf dan otot, memperlancar peredaran darah dan meningkatkan daya tahan tubuh ibu hamil. Manfaat langsung yang dirasakan antara lain nyeri punggung berkurang, kualitas tidur meningkat dan menimbulkan perasaan bahagia (Suarniti et al., 2019).

\section{SIMPULAN}

Terdapat pengaruh yang signifikan pada perubahan kualitas tidur ibu hamil trimester III sebelum dan sesudah diberikan pregnancy massage pada kelompok intervensi. 


\section{SARAN}

Hasil penelitian ini diharapkan dapat memberikan informasi pada ibu tentang manfaat pregnancy massage bagi ibu saat kehamilan. Disarankan bagi ibu hamil trimester III dapat mengikuti pregnancy massage secara teratur agar proses persalinannya dapat berjalan dengan lancar.

\section{DAFTAR PUSTAKA}

Bustami, L, E., Nurdiyan, A., Yulizawati, Y., Iryani, D., Fitrayeni, F., \& Insani, A. A. (2017). Pengaruh Kualitas Tidur Dengan kejadian Pre Eklamsia. Journal of Midwifery Research and Practice, 1(1), 35-44. DOI: https://doi.org/10.25077/jom.1.1.35-44.2016

Kurnia, J., Mulyadi, M., \& Rottie, J. (2017). Hubungan Kualitas Tidur dengan Kadar Glukosa Darah Puasa pada Pasien Diabetes Melitus Tipe 2 di Rumah Sakit Pancaran Kasih Gmim Manado. Jurnal Keperawatan UNSRAT, 5(1). https://ejournal.unsrat.ac.id/index.php/jkp/article/view/14946

Mariana, D., Wulandari, D., \& Padila, P. (2018). Hubungan Pola Makan dengan Kejadian Anemia pada Ibu Hamil di Wilayah Kerja Puskesmas. Jurnal Keperawatan Silampari, 1(2), 108-122. https://doi.org/https://doi.org/10.31539/jks.v1i2.83

Palifiana, D. A., \& Wulandari, S. (2018). Hubungan Ketidaknyamanan dalam Kehamilan dengan Kualitas Tidur Ibu Hamil Trimester III di Klinik Pratama Asih Waluyo Jati. Prosiding Seminar Nasional Seri 8, 31-40. https://dspace.uii.ac.id/handle/123456789/11435

Prananingrum, R., \& Hidayah, N. (2018). Efektifitas Loving Massage in Pregnancy terhadap Pola Tidur pada Ibu Hamil Primigravida. Gaster, 16(2), 168-176. DOI: 10.30787/gaster.v16i2.296

Rahayu, S, W., Pertiwi, S., \& Rohmatin, E. (2020). The Effect of Loving Pregnancy massage on Sleep Quality of Trimester III Pregnant Mother. Midwifery and Nursing Research, 2(2), 65-68. http://ejournal.poltekkessmg.ac.id/ojs/index.php/MANR/article/view/5131

Resmaniasih, K. (2018). Pengaruh Pijat Hamil terhadap Perubahan Kualitas Tidur Ibu Hamil Trimester Tiga. JIK: Jurnal Ilmu Kesehatan, 2(2), 93-99. https://jik.stikesalifah.ac.id/index.php/jurnalkes/article/view/124

Rufaida, Z., Lestari, S. W. P., \& Susanti, I. Y. (2020). Pregnancy Massage dengan Pola Tidur Ibu Hamil Trimester III di Desa Gebangmalang Kecamatan Mojoanyar Kabupaten Mojokerto. Hospital Majapahit, 12(1), 61-69. http://ejournal.stikesmajapahit.ac.id/index.php/HM/article/view/497

Suarniti, N. L, K Cahyaningrum, L, P., \& Wiryanatha, I, B. (2019). Terapi Pijat Ibu Hamil untuk Mengurangi Spasme Otot pada Masa Trimester Akhir Kehamilan. Jurnal Widya Kesehatan, 1(2), 11-19. DOI: https://doi.org/10.32795/widyakesehatan.v1i2.460

Sudarnanik, S., Fatoni, I., \& Ningrum, N. M. (2020). Pengaruh Prenatal Massage terhadap Proses Persalinan di Pustu Kedungprimpen Kecamatan Kanor Kabupaten Bojonegoro. Insan Cendekia Medika, 1-9. http://repo.stikesicme-jbg.ac.id/4425/

Sukorini, M, U. (2017). Hubungan Gangguan Kenyamanan Fisik dan Penyakit dengan Kualitas Tidur Ibu Hamil Trimester III. The Indonesian Journal of Public Health, 12(1), 1. https://e-journal.unair.ac.id/IJPH/article/view/7108 
Wardani, H, W., Agustina, R., \& Astika, E. (2018). Tingkat Kecemasan dengan Kualitas Tidur Ibu Hamil Primigravida Trimester III. Dunia Keperawatan, 6(1), 1-10. https://ppjp.ulm.ac.id/journal/index.php/JDK/article/download/4946/4265

Wati, L. S. (2018). Pengaruh Prenatal Massage terhadap Stres Kehamilan pada Primigravida Trimester III di BPM Lilis Surya Wati Sambong Dukuh Jombang. Jurnal Kebidanan Stikes Insan Cendikia Medika, 16(1). DOI: https://doi.org/10.35874/jib.v16i1.400

Yantina, Y., \& Evrianasari, N. (2020). Back Massage pada Kualitas Tidur Ibu Hamil Trimester III. Jurnal Kebidanan, 6(4), 408-412. http://ejurnalmalahayati.ac.id/index.php/kebidanan/article/view/3281

Yusmaharani, Y. (2019). Hubungan Dukungan Suami dengan Pemanfaatan Kelas Ibu Hamil. Jurnal Kesmas Asclepius, 1(2), 86-95. https://doi.org/ https:// doi. org/ 10. 31 539/jka.v1i2.586 